\title{
Using Process Maps to Understand How Engineering Students Conceptualize Innovation
}

\section{Mr. Nicholas D. Fila, Purdue University, West Lafayette (College of Engineering)}

Nicholas D. Fila is a Ph.D. candidate in the School of Engineering Education at Purdue University. He earned a B.S. in Electrical Engineering and a M.S. in Electrical and Computer Engineering from the University of Illinois at Urbana-Champaign. His current research interests include innovation, empathy, and engineering design.

\section{Dr. Senay Purzer, Purdue University, West Lafayette (College of Engineering)}

Senay Purzer is an Associate Professor in the School of Engineering Education. She is the recipient of a 2012 NSF CAREER award, which examines how engineering students approach innovation. She serves on the editorial boards of Science Education and the Journal of Pre-College Engineering Education (JPEER). She received a B.S.E with distinction in Engineering in 2009 and a B.S. degree in Physics Education in 1999. Her M.A. and Ph.D. degrees are in Science Education from Arizona State University earned in 2002 and 2008, respectively.

\section{Mr. Austin Spencer Bohlin, Purdue University, West Lafayette (College of Engineering)}

I am a sophomore in mechanical engineering at Purdue University. I am currently working as an undergraduate research assistant for the Engineering Education department through INSPIRE. 


\section{Using Process Maps to Understand How Engineering Students Conceptualize Innovation}

\section{Introduction}

Innovation has become a critical competency for engineering students ${ }^{1,2}$. Engineers are called upon to understand and develop solutions to increasingly complex and challenging problems and produce greater value for a variety of stakeholders. Current research on engineering students and their connection to innovation has focused on two key areas. First, researchers have developed and utilized students assessments based on the knowledge, skills, and attitudes of expert innovators and entrepreneurs ${ }^{3-6}$. Second, researchers have analyzed project deliverables and conceptual design outcomes as meaningful representations represent students' innovation competency. $^{7-9}$

Yet, innovation is a complex phenomenon. Current understanding of innovation involves not only outcomes and individual characteristics, but the environments that support innovative outcomes ${ }^{10-12}$, and more prominently, the processes that innovators ${ }^{13,14}$ and innovative teams organizations ${ }^{15}$ utilize. In this study, we investigate the breadth of student understanding of innovation processes. More specifically, we ask:

1. To what extent do engineering students acknowledge unique phases of innovation as part of their personal innovation processes?

2. To what extent do engineering students acknowledge technological, strategic, societal, financial, competitor, and human considerations as part of their personal innovation processes?

\section{Literature Review}

\section{Frameworks for describing innovation processes}

In 1966, economist Robert Johnson summarized the innovation process into four stages:

1. Initial idea or need recognition which leads to research.

2. Decision of technical and economic feasibility which leads to development of the idea and testing of a prototype and trail production runs.

3. Commercial production of the product. Note that innovation still continues during this step in the form of improvements to the initial innovation and diffusion of the innovation to other firms and industries.

4. A further stage of the diffusion from the nation level to the international level.

Ford and colleagues simplified this definition into 3 stages $^{15}$. Stage 1 focused on basic research. Stage 2 consisted of working through the technical and economic problems with the goal of reaching a feasible solution. Stage 3 consisted of commercial production and diffusion of the solution. While, at a macro level, these definitions capture the essence of the innovation process, neither demonstrates how innovation occurs at a micro level (i.e., for individual innovators). 
Further studies have explored the unique processes innovators utilize. Some of these studies attempt to form composite models of innovators' processes (e.g., to identify common pathways to innovation). For example, Griffin and colleagues ${ }^{13}$ interviewed serial innovators from a diverse array of industries. They identified an "hourglass model" of the innovation process that was defined by five key objectives and their interplay (pg. 1366):

- Finding an interesting problem

- Understanding the problem completely

- Inventing a solution to the problem and validating it with customers and the firm

- Executing the firm's formal development process to turn the problem solution into a sellable product

- Creating market acceptance for the product

Other researchers have embraced breadth in innovators' processes. Golish and colleagues ${ }^{14}$, for example, explored the stages and issues academic and professional innovators in the RFID industry incorporated into their processes along a two-dimensional framework. This framework incorporated five stages (opportunity identification, design and development, testing and preproduction, introduction and production, and life-cycle management) as well as six issue areas (technological, strategic, financial, societal, human (resources), and competitor). ${ }^{14}$ The stage dimension aligned with Ford and colleagues' macro-level process (e.g., Ford and colleagues' Stage 2 incorporates Design and Development and Testing and Preproduction). Within this framework, Golish and colleagues identified 133 elements (e.g., idea generation) from literature and open-ended participant responses that individual innovators utilized to build their processes. Hence the micro-level innovation processes can be both a complex and diverse, varying from innovator to innovator. Golish and colleagues' framework can be used to inform an understanding of the focus and comprehensiveness of individual innovator's process.

\section{Measuring understanding of the innovation process among engineering students}

Alongside the push to identify innovative attributes and outcomes among engineering students, assessments of these areas have come into recent focus. For example, a 2016 review explored the methods used to assess engineering student competencies related to engineering entrepreneurship and innovation ${ }^{5}$. Assessments tended to focus on a variety of knowledge, skills, and attitudes, and most often took the form of self-report surveys and project deliverables. Additionally, idea generation and conceptual design tasks have been used to determine innovation competency ${ }^{6,7,16}$. While these assessments have provided insights into different aspects of innovation competency, additional assessments are needed to explore the comprehensiveness with which engineering students understand the innovation process, and the specific elements of the process that they emphasize. Previous studies have demonstrated process maps ${ }^{17,18}$ as a visual assessment tool that can provide a quick and effective evaluation of an individuals' understanding of the innovation process. 


\section{Methods}

We utilized quantitative content analysis ${ }^{19}$ to investigate the extent to which students included the distinct phases and focus areas of the innovation process in their process maps. This analysis is guided by the innovation process framework developed by Golish and colleagues. ${ }^{14}$

\section{Participants}

Thirty-two engineering students from a large research university participated in this study. Participants were recruited from a variety of organizations and courses and through a series listserv emails and fliers across campus. This method allowed us to reach a broad cross-section of the student population, especially those who participated in a variety of innovation-related projects (including personal projects, course projects, design competitions, service learning projects, internship and co-op, and new start-ups). Demographically, the sample was composed of 25 seniors and 7 first-year students across nine different engineering majors; 15 females and 17 males; and 12 students self-identified as Asian, 18 self-identified as white, and 2 students preferred not to identify race/ethnicity.

\section{Data Collection}

Students each participated in a two-hour interview protocol containing five stages: background interview, process mapping task, idea generation task, innovation content interview, and closing remarks. The current study focuses on data from the process mapping task only. Utilizing a think aloud protocol, participants were given thirty minutes to sketch and discuss an innovation process map. Students were prompted to include stages or activities students would perform to "identify, develop, and implement an innovative design solution," but were not given explicit instructions related to the form or structure the process map would take. After students completed their process maps, they also completed a semi-structured debriefing interview to provide additional details related to the content and motivation of their process maps. We utilized smartpen and audio-video recordings, as well as physical copies of the process maps, to capture both visual and verbal representations of the students' innovation processes (i.e., a realtime account of students' descriptions of their innovation processes and the development of the process maps).

\section{Data Analysis}

We utilized 31 of the participants' process maps as data in this study. One participant's process map was not used in analysis because it did not address the given prompt (it focused on how he would solve a standard statics homework problem). We began coding the process maps with an a priori coding protocol based on the work of Golish, Shuman, and Besterfield-Sacre. ${ }^{14}$ Golish and colleagues' study investigated the technology development processes of expert 11 academic and industry innovators. This coding protocol identified six distinct focus areas (technological, strategic, societal, financial, competitor, and human resources) across five distinct phases of innovation (opportunity identification, design and development, testing and preproduction, introduction and production, and life-cycle management). Initial codes represented each of the thirty potential combinations of the phases and focus areas. 
Since Golish and colleagues' study focused on professional innovators and utilized a list of potential stages, rather than allowing freeform process map development, we performed an initial open coding stage to explore the types of activities students listed and refine/elaborate definitions of the a priori codes. We underwent four iterations of open coding, refining the codebook at each stage, until code definitions and examples stabilized and two authors agreed on the structure. After this initial coding phase, we axially coded all 31 process maps and checked inter-rater agreement. The levels of agreement were acceptable (Cohen's kappa was .82 for the phase dimension and .78 for the focus area dimension). Two authors discussed the remaining coding differences and reached agreement on all coded elements. A copy of the final codebook is included as an appendix.

Maps were initially coded using only visual elements, however the meanings of some visual elements were unclear. The smartpen audio-video recordings were used to give the researchers a clearer understanding of the students' meanings with relation to specific elements and how they fit into the process maps.

\section{Results}

\section{Frequency of Innovation Phases}

We first investigated the number of process map elements that were aligned with each innovation phase. Figure 1 demonstrates that participants emphasized the initial stages of innovation, especially opportunity identification, and decreased emphasis with each successive phase. There were few instances of life-cycle management, demonstrating limited considering of innovation after the solution has been introduced.

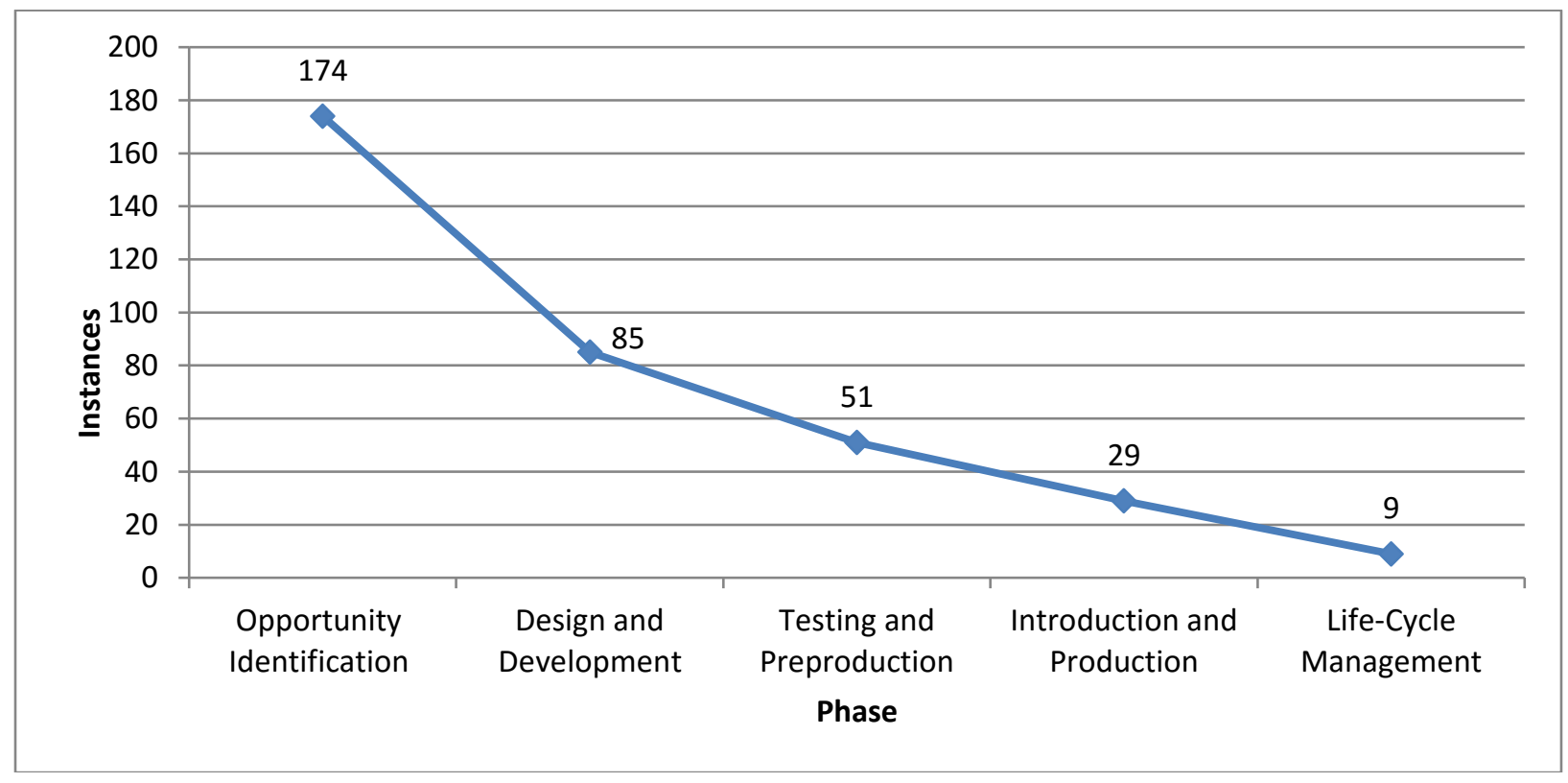

Figure 1. Instances of each phase in participant process maps 


\section{Frequency of Innovation Focus Areas}

Next, we explored the instances of each focus area in participant process maps. Figure 2 shows that the most observed focus area was technology, followed by strategic, societal, human (resources), financial, and competitor issues. Technological elements accounted for $46 \%$ of the coded elements, demonstrating an overwhelming emphasis on these issues with relation to the innovation process. While some of the business-related focus areas were common (e.g., strategic accounted for $23 \%$ of the process elements), only five total elements considered competitor issues.

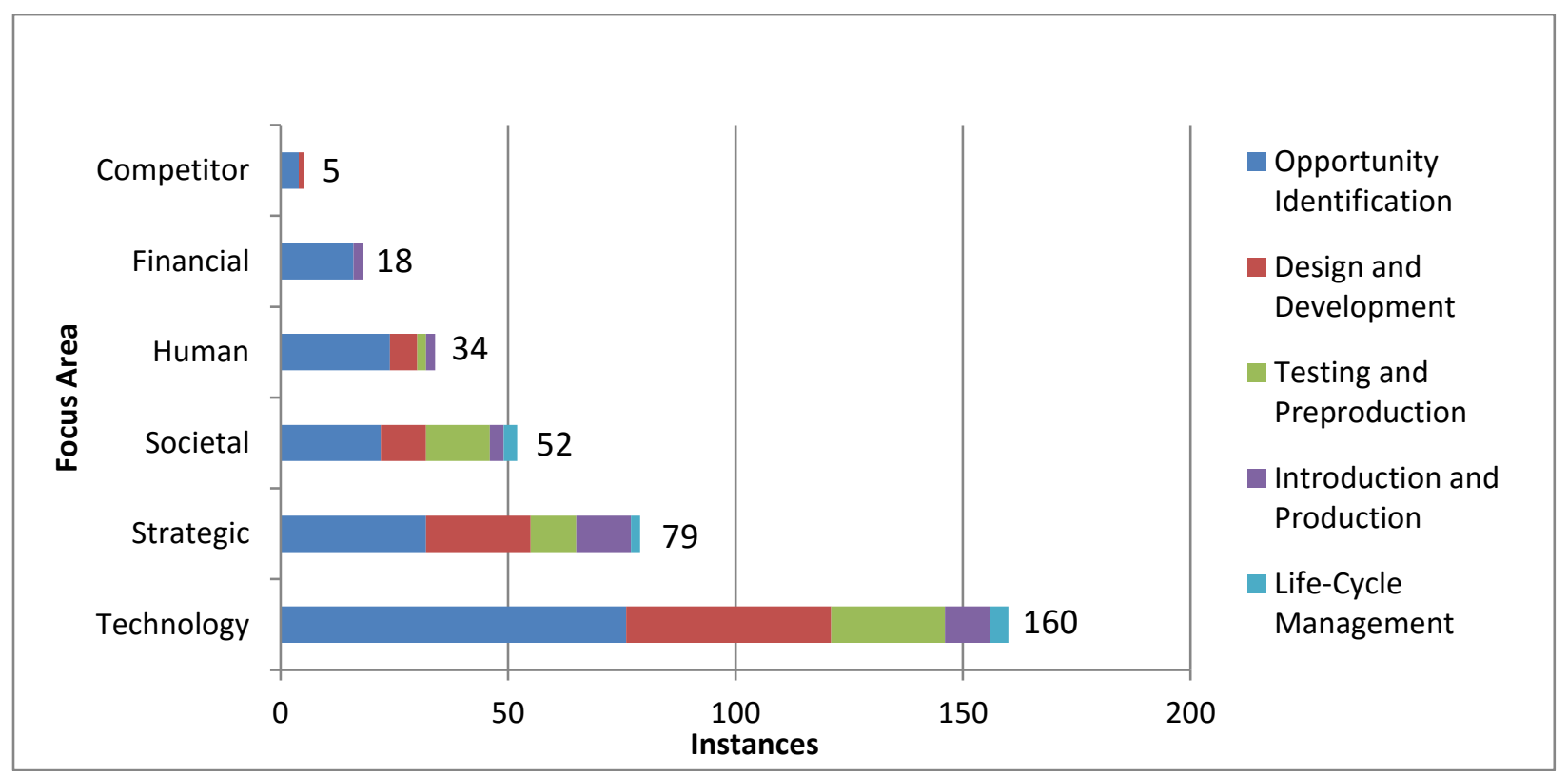

Figure 2. Instances of each focus area in student process maps

\section{Frequency of Phase-Focus Area Combinations}

Table 1 presents a breakdown of the coded elements by combinations of phase and focus area. The general trends (i.e., a non-uniform distribution) from the individual dimensions are largely consistent here. However, this table also demonstrates specific phase-focus area combinations that were not observed in any of the process maps (such as financial-design and development), and focus areas that were predominantly observed in particular phases. For example, both human resources and financial elements occurred most frequently during the opportunity identification phase. In exploring the individual maps, these trends can be attributed to multiple elements related to team formation (human resources) and securing funding for the project (financial).

Table 2 presents an alternative perspective on the results in Table 1. Instead of exploring the number of instances of each code, Table 2 presents the number of participants (out of 31) who included at least one instance of each phase-focus area combination in their process map. These results demonstrated a similar trend to those in Table 1, but they show an increased relative emphasis on societal and human resources considerations. For example, $84 \%$ of students identified at least one societal element in their process map, compared to $71 \%$ for strategic 
elements, despite strategic representing 52\% more coded elements than societal. Further, these results demonstrate that many of the phases and focus areas were acknowledged by at least half of the participants.

Table 1: Total Instances of Focus Area-Phase Combinations

\begin{tabular}{|l|c|c|c|c|c|c|c|}
\hline & \multicolumn{7}{|c|}{ Focus Area } \\
\cline { 2 - 8 } & Technology & Strategic & Societal & $\begin{array}{l}\text { Human } \\
\text { Resources }\end{array}$ & Financial & Competitor & Total \\
\hline $\begin{array}{l}\text { Opportunity } \\
\text { Identification }\end{array}$ & 76 & 32 & 22 & 24 & 16 & 4 & 174 \\
\hline $\begin{array}{l}\text { Design and } \\
\text { Development }\end{array}$ & 45 & 23 & 10 & 6 & 0 & 1 & 85 \\
\hline $\begin{array}{l}\text { Testing and } \\
\text { Preproduction }\end{array}$ & 25 & 10 & 14 & 2 & 0 & 0 & 51 \\
\hline $\begin{array}{l}\text { Production } \\
\text { and } \\
\text { Introduction }\end{array}$ & 10 & 12 & 3 & 2 & 2 & 0 & 29 \\
\hline $\begin{array}{l}\text { Life Cycle } \\
\text { Management }\end{array}$ & 4 & 2 & 3 & 0 & 0 & 0 & 9 \\
\hline Total & 160 & 79 & 52 & 34 & 18 & 5 & 348 \\
\hline
\end{tabular}

Table 2: Total Number of Students Who Included Each Focus Area-Phase Combination in Their Process Map

\begin{tabular}{|c|c|c|c|c|c|c|c|}
\hline \multirow[b]{2}{*}{ Phase } & \multicolumn{7}{|c|}{ Focus Area } \\
\hline & Technology & Strategic & Societal & $\begin{array}{l}\text { Human } \\
\text { Resources }\end{array}$ & Financial & Competitor & Total \\
\hline $\begin{array}{l}\text { Opportunity } \\
\text { Identification }\end{array}$ & 27 & 18 & 18 & 18 & 12 & 3 & 31 \\
\hline $\begin{array}{l}\text { Design and } \\
\text { Development }\end{array}$ & 25 & 12 & 9 & 6 & 0 & 1 & 29 \\
\hline $\begin{array}{l}\text { Testing and } \\
\text { Preproduction }\end{array}$ & 18 & 9 & 12 & 2 & 0 & 0 & 24 \\
\hline $\begin{array}{l}\text { Production } \\
\text { and } \\
\text { Introduction }\end{array}$ & 10 & 9 & 3 & 1 & 2 & 0 & 15 \\
\hline $\begin{array}{l}\text { Life Cycle } \\
\text { Management }\end{array}$ & 4 & 2 & 3 & 0 & 0 & 0 & 5 \\
\hline Total & 31 & 22 & 26 & 20 & 12 & 4 & 31 \\
\hline
\end{tabular}




\section{Discussion and Conclusions}

Both the phase and focus area dimensions demonstrated exponential decay-shaped trends with respect to the total instances of each element featured across all process maps. In the phase dimension, this trend demonstrated diminishing instances of phases from the front end of innovation to the back end. It is not surprising that students favored early stages such as opportunity identification and design and development as these are the phases that are most common to curricular design activities (e.g., concept generation, modeling, and prototyping activities). Further, results from Golish and colleagues ${ }^{14}$ study demonstrates a similar trend, i.e., there may be more unique tasks to complete during these early stages as projects are initiated and developed.

The decay trend along the focus area dimension represents a strong preference for technological issues, a moderate preference for strategic and societal issues, and less consideration of human resources, financial, and competitor issues. Once again, this result is not surprising due to the strong technical focus of much engineering curricula. Further, a comprehensive list of potential activities in each focus area shows only a limited number of competitor-related and financial aspects. ${ }^{14}$

Still, fewer than half of the participants included a production and introduction or life-cycle management element in the phase dimension or financial or competitor elements in the focus area dimension. Various combinations of these underrepresented elements (e.g., consideration of competitor issues during production and introduction) were missing from all process maps. The lack of representation, and even omission, of these phases, focus areas, and combinations thereof shows a potential challenge for many engineering students as they enter the professional arena and participate in higher stakes innovation projects. Better preparedness on these underrepresented aspects, especially innovation beyond opportunity identification, design and development, and testing, could be appropriate. Future work may focus on exploring why these areas are underrepresented and how instruction and innovation activities can support more expansive understanding and awareness in these areas.

\section{Acknowledgement}

This material is based upon work supported by the National Science Foundation Engineering Education Program under Grant No. 1150874. Any opinions, findings and conclusions or recommendations expressed in this material are those of the authors and do not necessarily reflect the views of the National Science Foundation.

\section{References}

1. Radcliffe, D. F. Innovation as a meta-attribute for graduate engineers. Int. J. Eng. Educ. 21, 194-199 (2005).

2. Ferguson, D. M., Cawthorne, J. E., Ahn, B. \& Ohland, M. W. Engineering innovativeness. J. Eng. Entrep. 4, 1-16 (2013).

3. Duval-Couetil, N. \& Dyrenfurth, M. Teaching students to be innovators: Examining 
competencies and approaches across disciplines. Int. J. Innov. Sci. 4, 143-154 (2012).

4. Besterfield-Sacre, M. E. et al. Essential factors related to entrepreneurial knowledge in the engineering curriculum. In 2012 American Society for Engineering Education Annual Conference and Exposition (2012).

5. Purzer, Ş., Fila, N. D., \& Nataraja, K. M. Evaluation of current assessment methods in engineering entrepreneurship education. Advances in Engineering Education, 5, 1-27 (2016).

6. Charyton, C., Jagacinski, R. J., Merrill, J. A., Clifton, W. \& DeDios, S. Assessing creativity specific to engineering with the revised creative engineering design assessment. J. Eng. Educ. 100, 778-799 (2011).

7. Genco, N., Hölttä-Otto, K. \& Seepersad, C. C. An experimental investigation of the innovation capabilities of undergraduate engineering students. J. Eng. Educ. 101, 60-81 (2012).

8. Fila, N.D. \& Purzer, S. The relationship between team gender diversity, idea variety, and potential for design innovation. International Journal of Engineering Education 30, 14051418 (2014).

9. Svihla, V., Petrosino, A. J. \& Diller, K. R. Learning to design: Authenticity, negotiation, and innovation. Int. J. Eng. Educ. 28, 782-798 (2012).

10. Buschgens, T., Bausch, A. \& Balkin, D. B. Organizational culture and innovation: A meta-analytic review. J. Prod. Innov. Manag. 30, 763-781 (2013).

11. Hauschildt, J. \& Kirchmann, E. Teamwork for innovation - the 'troika' of promotors. $R D$ Manag. 31, 41-49 (2001).

12. Petre, M. How expert engineering teams use disciplines of innovation. Des. Stud. 25, 477493 (2004).

13. Griffin, A., Price, R. L., Vojak, B. A. \& Hoffman, N. Serial innovators' processes: How they overcome barriers to creating radical innovations. Ind. Mark. Manag. 43, 1362-1371 (2014).

14. Golish, B. L., Besterfield-Sacre, M. E. \& Shuman, L. J. Comparing academic and corporate development process. J. Prod. Innov. Manag. 25, 47-62 (2008).

15. Ford, G. S., Koutsky, T. M. \& Spiwak, L. J. An economic investigation of the valley of death in the innovation sequence. (2007).

16. Kershaw, T. C., Peterson, R. L., Mccarthy, M. a, Williams, P. T. \& Young, A. P. Detc2015-47650. 1-10 (2015).

17. Purzer, Ş. \& Fila. N. D. Indicators of creative and entrepreneurial thinking among engineering and technology students, In 2013 ASEE Annual Conference \& Exposition (Atlanta, GA, 2013)

18. Fernandez, T., Purzer, Ş. \& Fila. N. D. Using process mapping to understand engineering students' conceptions of innovation processes. In 2016 Frontiers in Education Conference (Erie, PA, 2016)

19. Krippendorff, K. Content analysis: An introduction to its methodology. (Sage, 2012). 


\section{Appendix: Coding Protocol and Examples}

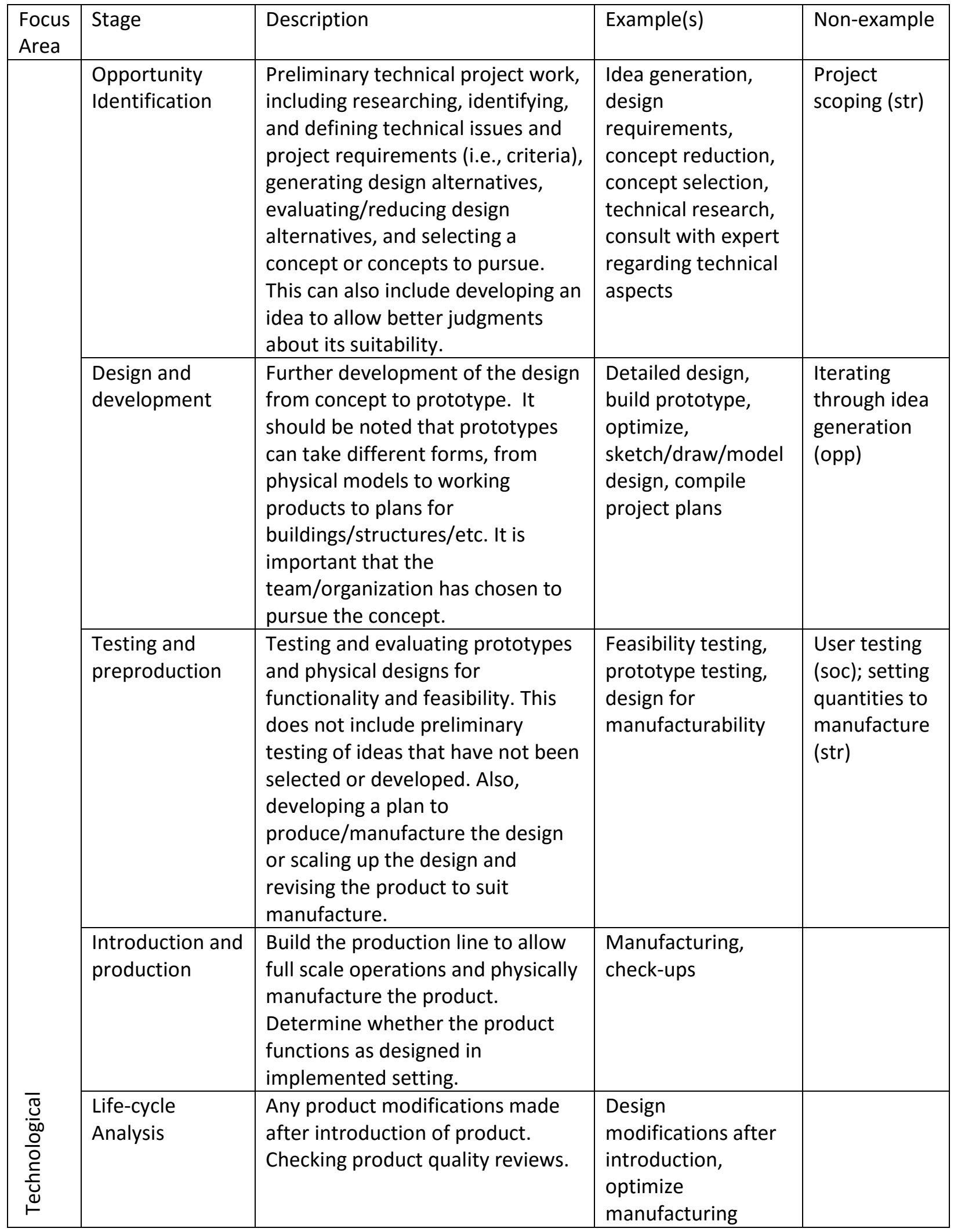




\begin{tabular}{|c|c|c|c|c|}
\hline & $\begin{array}{l}\text { Opportunity } \\
\text { Identification }\end{array}$ & $\begin{array}{l}\text { Identifying the target } \\
\text { customer/stakeholders and their } \\
\text { general needs either through } \\
\text { observation, communication, or } \\
\text { other research. This does not } \\
\text { include specific needs related to an } \\
\text { in-development product. Customer } \\
\text { understanding can lead to } \\
\text { identifying viability of the project } \\
\text { and setting functional goals for the } \\
\text { product, but these steps are not } \\
\text { included in this code. }\end{array}$ & $\begin{array}{l}\text { Identify user, } \\
\text { identify } \\
\text { problem/user needs }\end{array}$ & $\begin{array}{l}\text { Defining } \\
\text { requirements } \\
\text { based on } \\
\text { customer } \\
\text { needs (tech); } \\
\text { Customer } \\
\text { survey for } \\
\text { pricing } \\
\text { (Financial) or } \\
\text { viability } \\
\text { (Strategic) }\end{array}$ \\
\hline & $\begin{array}{l}\text { Design and } \\
\text { development }\end{array}$ & $\begin{array}{l}\text { Analyzing and clarifying customer } \\
\text { needs and potential social, } \\
\text { political, human factors, and } \\
\text { environmental impact of the } \\
\text { product. Planning to modify the } \\
\text { design or design requirements } \\
\text { based on this customer and } \\
\text { societal understanding. }\end{array}$ & $\begin{array}{l}\text { Customer needs } \\
\text { analysis, check } \\
\text { regulations and } \\
\text { legality, design for } \\
\text { sustainability }\end{array}$ & $\begin{array}{l}\text { Setting } \\
\text { requirements } \\
\text { (tech), design } \\
\text { modifications } \\
\text { based on } \\
\text { user input } \\
\text { (tech) }\end{array}$ \\
\hline & $\begin{array}{l}\text { Testing and } \\
\text { preproduction }\end{array}$ & $\begin{array}{l}\text { Testing and evaluating the } \\
\text { prototype or physical design with } \\
\text { users/from a user perspective. } \\
\text { Addressing user/operator issues in } \\
\text { product use, manufacturing, and } \\
\text { customer support. }\end{array}$ & $\begin{array}{l}\text { User testing, } \\
\text { product education, } \\
\text { customer service, } \\
\text { regulatory testing }\end{array}$ & $\begin{array}{l}\text { Testing with } \\
\text { users for } \\
\text { functionality } \\
\text { (tech) }\end{array}$ \\
\hline & $\begin{array}{l}\text { Introduction and } \\
\text { production }\end{array}$ & $\begin{array}{l}\text { Evaluating actual societal (user, } \\
\text { environment, political) impact of } \\
\text { and reactions to the project. }\end{array}$ & $\begin{array}{l}\text { Customer feedback } \\
\text { evaluation }\end{array}$ & $\begin{array}{l}\text { Acting on } \\
\text { customer } \\
\text { feedback (LC) }\end{array}$ \\
\hline $\begin{array}{l}\bar{\pi} \\
\frac{\pi}{4} \\
0 \\
0\end{array}$ & $\begin{array}{l}\text { Life-cycle } \\
\text { Analysis }\end{array}$ & $\begin{array}{l}\text { Handle product warranties and } \\
\text { evaluating ongoing customer } \\
\text { opinion and changing needs with } \\
\text { relation to the product. }\end{array}$ & $\begin{array}{l}\text { Determination of } \\
\text { changing customer } \\
\text { needs }\end{array}$ & \\
\hline 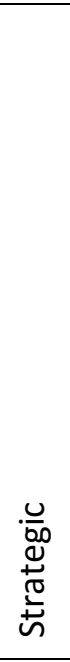 & $\begin{array}{l}\text { Opportunity } \\
\text { Identification }\end{array}$ & $\begin{array}{l}\text { Identify market opportunities. } \\
\text { Evaluate product ideas for their } \\
\text { potential to reach a sufficient } \\
\text { market share (i.e., number of } \\
\text { customers). Set the scope the } \\
\text { project, including determining the } \\
\text { market and market category to } \\
\text { pursue and setting rough } \\
\text { goals/timeline for product/product } \\
\text { line. Performing due diligence with } \\
\text { reference to market and } \\
\text { sales/distribution channels. Rough } \\
\text { plans for the product future can be } \\
\text { included here as long as they are }\end{array}$ & $\begin{array}{l}\text { Market analysis, risk } \\
\text { assessment, project } \\
\text { scoping, product } \\
\text { timeline, early } \\
\text { estimate of market } \\
\text { share/quantity sold }\end{array}$ & $\begin{array}{l}\text { Market } \\
\text { analysis } \\
\text { (when used } \\
\text { to identify } \\
\text { customer } \\
\text { needs) (soc) }\end{array}$ \\
\hline
\end{tabular}




\begin{tabular}{|c|c|c|c|c|}
\hline & & $\begin{array}{l}\text { intended to assess viability rather } \\
\text { than determine the course of an } \\
\text { in-development product/design. }\end{array}$ & & \\
\hline & $\begin{array}{l}\text { Design and } \\
\text { development }\end{array}$ & $\begin{array}{l}\text { Identify unique, innovative, and } \\
\text { competitive aspects of your design } \\
\text { in order to clarify market and } \\
\text { further plans for product. Develop } \\
\text { a plan to market, advertise, } \\
\text { produce, and distribute the in- } \\
\text { development design (including } \\
\text { quantities and markets). Work } \\
\text { through patents, licensing, and } \\
\text { other business affairs. Planning } \\
\text { logistics of the project. }\end{array}$ & $\begin{array}{l}\text { Filing a patent, } \\
\text { develop marketing } \\
\text { plan, identify key } \\
\text { innovation, evaluate } \\
\text { logistics, set } \\
\text { production } \\
\text { quantities }\end{array}$ & $\begin{array}{l}\text { Act of } \\
\text { advertising } \\
\text { (prod) }\end{array}$ \\
\hline & $\begin{array}{l}\text { Testing and } \\
\text { preproduction }\end{array}$ & $\begin{array}{l}\text { Test/check the viability of the } \\
\text { product through a limited rollout, } \\
\text { other consumer trial/interview, or } \\
\text { analysis of a product at least at the } \\
\text { prototype stage. Identify future } \\
\text { product opportunities, including } \\
\text { extending the lifetime of the } \\
\text { developed product line and } \\
\text { developing complementary } \\
\text { products. }\end{array}$ & $\begin{array}{l}\text { Minimum viable } \\
\text { product, test } \\
\text { marketing, focus } \\
\text { group with } \\
\text { marketing focus, } \\
\text { final checks }\end{array}$ & $\begin{array}{l}\text { Sending } \\
\text { established } \\
\text { product to a } \\
\text { new market } \\
\text { (prod) }\end{array}$ \\
\hline & $\begin{array}{l}\text { Introduction and } \\
\text { production }\end{array}$ & $\begin{array}{l}\text { Evaluate lessons learned from the } \\
\text { project overall and identify future } \\
\text { plans for the product. Physical act } \\
\text { of advertising, distributing, and/or } \\
\text { implementing the product to the } \\
\text { target market. }\end{array}$ & $\begin{array}{l}\text { Advertising, } \\
\text { evaluate project, set } \\
\text { up an online store, } \\
\text { bring to market } \\
\text { (with sufficient } \\
\text { elaboration of } \\
\text { activity) }\end{array}$ & \\
\hline & $\begin{array}{l}\text { Life-cycle } \\
\text { Analysis }\end{array}$ & $\begin{array}{l}\text { Determine how to phase out the } \\
\text { product and next steps for } \\
\text { potential new product. }\end{array}$ & Plan for future & \\
\hline \multirow[b]{3}{*}{$\begin{array}{l}\frac{\bar{\pi}}{\frac{\pi}{0}} \\
\frac{\Gamma}{\pi} \\
i \frac{\pi}{4}\end{array}$} & $\begin{array}{l}\text { Opportunity } \\
\text { Identification }\end{array}$ & $\begin{array}{l}\text { Initial financial planning and } \\
\text { analysis for the project, including } \\
\text { setting target prices, estimating } \\
\text { profit, determining costs, setting a } \\
\text { budget, identifying financial risks, } \\
\text { and securing funding. }\end{array}$ & $\begin{array}{l}\text { Secure funding, } \\
\text { ensure profit, set } \\
\text { budget }\end{array}$ & $\begin{array}{l}\text { Listing cost- } \\
\text { effectiveness } \\
\text { as a design } \\
\text { requirement } \\
\text { (tech); } \\
\text { assessing } \\
\text { viability (str) }\end{array}$ \\
\hline & $\begin{array}{l}\text { Design and } \\
\text { development }\end{array}$ & $\begin{array}{l}\text { Forecasting potential sales of in- } \\
\text { development product. }\end{array}$ & Sales forecasting & \\
\hline & $\begin{array}{l}\text { Testing and } \\
\text { preproduction }\end{array}$ & $\begin{array}{l}\text { Analyzing whether the design is } \\
\text { within budget/target cost and } \\
\text { performing customer-related } \\
\text { financial assessments. }\end{array}$ & $\begin{array}{l}\text { Check budget, } \\
\text { pricing survey }\end{array}$ & \\
\hline
\end{tabular}




\begin{tabular}{|c|c|c|c|c|}
\hline & $\begin{array}{l}\text { Introduction and } \\
\text { production }\end{array}$ & $\begin{array}{l}\text { Final financial reviews, including } \\
\text { budget and profit analysis. }\end{array}$ & $\begin{array}{l}\text { Profit analysis; } \\
\text { analyze sales }\end{array}$ & \\
\hline & $\begin{array}{l}\text { Life-cycle } \\
\text { Analysis }\end{array}$ & $\begin{array}{l}\text { Analysis the cost for the life cycle } \\
\text { of the project/product. }\end{array}$ & & \\
\hline \multirow{5}{*}{ 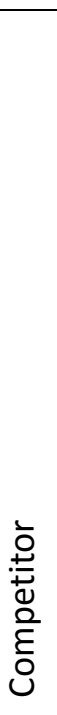 } & $\begin{array}{l}\text { Opportunity } \\
\text { Identification }\end{array}$ & $\begin{array}{l}\text { Analyzing current alternatives in } \\
\text { the market and competitor } \\
\text { positioning, with a focus on } \\
\text { understanding the competitors in } \\
\text { the market, not on supporting } \\
\text { design ideas. }\end{array}$ & $\begin{array}{l}\text { Competitor } \\
\text { benchmarking, } \\
\text { market research } \\
\text { (focused on existing } \\
\text { products). }\end{array}$ & $\begin{array}{l}\text { Reverse } \\
\text { engineering } \\
\text { (tech); prior } \\
\text { art (tech) }\end{array}$ \\
\hline & $\begin{array}{l}\text { Design and } \\
\text { development }\end{array}$ & $\begin{array}{l}\text { Making a plan to hinder } \\
\text { competitor operations (not related } \\
\text { specifically to your own product). }\end{array}$ & $\begin{array}{l}\text { Plan to influence } \\
\text { legislation affecting } \\
\text { competitor }\end{array}$ & \\
\hline & $\begin{array}{l}\text { Testing and } \\
\text { preproduction }\end{array}$ & $\begin{array}{l}\text { Anticipate how your competitors } \\
\text { will respond to product launch. }\end{array}$ & & \\
\hline & $\begin{array}{l}\text { Introduction and } \\
\text { production }\end{array}$ & $\mathrm{N} / \mathrm{A}$ & & \\
\hline & $\begin{array}{l}\text { Life-cycle } \\
\text { Analysis }\end{array}$ & $\begin{array}{l}\text { Analyze competitor response to } \\
\text { full-scale launch. }\end{array}$ & & \\
\hline \multirow{5}{*}{ 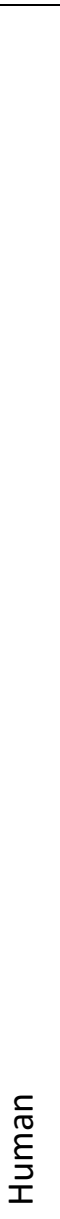 } & $\begin{array}{l}\text { Opportunity } \\
\text { Identification }\end{array}$ & $\begin{array}{l}\text { Organizing the project team and } \\
\text { planning work modes, schedules, } \\
\text { communication, task delegation. } \\
\text { Proposing a potential project to } \\
\text { superiors and } \\
\text { communicating/seeking approval } \\
\text { on a concept to pursue. }\end{array}$ & $\begin{array}{l}\text { Team formation, } \\
\text { scheduling, plan } \\
\text { meeting, project } \\
\text { proposal }\end{array}$ & $\begin{array}{l}\text { Consulting an } \\
\text { expert for } \\
\text { technical } \\
\text { research } \\
\text { (tech) }\end{array}$ \\
\hline & $\begin{array}{l}\text { Design and } \\
\text { development }\end{array}$ & $\begin{array}{l}\text { Adding team members, hiring } \\
\text { consulting based on emergent } \\
\text { issues or problems, or } \\
\text { restructuring teams during design } \\
\text { and development. } \\
\text { Communicating/seeking approval } \\
\text { for completed design plans. }\end{array}$ & $\begin{array}{l}\text { Ask expert, team } \\
\text { formation iteration }\end{array}$ & \\
\hline & $\begin{array}{l}\text { Testing and } \\
\text { preproduction }\end{array}$ & $\begin{array}{l}\text { Hiring an outside firm or } \\
\text { consultant to support product } \\
\text { testing, preproduction, or other } \\
\text { stages the participant will not } \\
\text { complete but are necessary to } \\
\text { innovation. } \\
\text { Communicating/seeking approval } \\
\text { to move to production. }\end{array}$ & Outsourcing & \\
\hline & $\begin{array}{l}\text { Introduction and } \\
\text { production }\end{array}$ & Create data management system. & & \\
\hline & $\begin{array}{l}\text { Life-cycle } \\
\text { Analysis }\end{array}$ & $\begin{array}{l}\text { Redistribute human resources to } \\
\text { other projects }\end{array}$ & Break-up team & \\
\hline
\end{tabular}

